\title{
VISITORS' HAPPINESS AND LOYALTY IN THE MORAVIAN WINE REGION
}

\author{
Andrea Králiková ${ }^{1}$, Patrik Kubát ${ }^{2}$, Kateřina Ryglováa
}

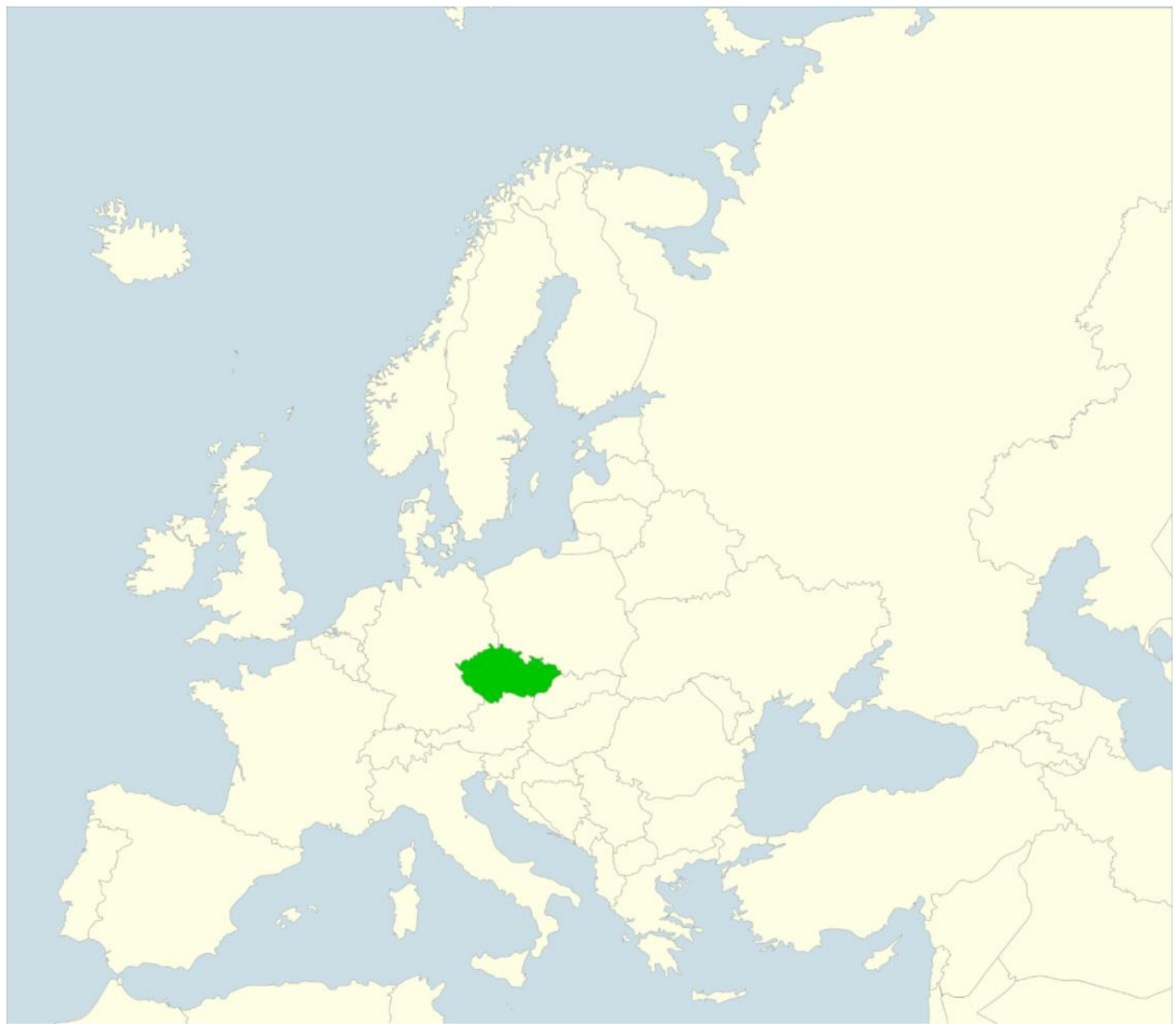

\footnotetext{
1 Ing. Andrea Králiková, Ph.D. student, Mendel University in Brno, Faculty of Business and Economics, e-mail: andrea.kralikova@mendelu.cz, ORCID: 0000-0002-5900-8766

2 Ing. Patrik Kubát, Ph.D. student, Mendel University in Brno, Faculty of Business and Economics, e-mail: patrik.kubat@mendelu.cz, ORCID: 0000-0002-7407-5107

3 Ing. Kateřina Ryglová, Ph.D., Ass. Prof., Mendel University in Brno, Faculty of Business and Economics, e-mail: katerina.ryglova@mendelu.cz, ORCID: 0000-0001-8511-5437
} 
Abstract: Due to the COVID-19 pandemic, tourists' loyalty is more pronounced than ever. It is therefore inevitable to know what factors can contribute to the higher levels of loyalty among potential visitors. Since none of the previously researched factors are reflecting visitors' feelings and emotions, and because wine tourism can build long-lasting emotional ties with tourists, this study focuses on Moravian wine region visitors' happiness within the context of loyalty. Overall, seven loyalty factors influence the happiness indicators: quality of wine, relaxation, information about wine, natural attractions, friendly acceptance by the locals, wine culture and traditions, as well as vineyard excursions. Furthermore, this study also confirms the dependence the happiness perception has on visitors' characteristics, such as gender, income, or with whom they visited the destination. The results of the study can be used to restart and support the development of sustainable tourism in the regions.

Key Words: visitors' happiness, loyalty, wine tourism, rural development, the Czech Republic

\begin{abstract}
Abstrakt: Následkem pandemie COVID-19 je loajalita turistů významnější než kdy dříve. Je proto potřeba znát jaké faktory mohou přispět $\mathrm{k}$ vyšší úrovni loajality mezi potenciálními návštěvníky. Jelikož žádný z dříve zkoumaných faktorů neodráží pocity a emoce návštěvníků a skutečnost, že vinařská turistika mưže budovat dlouhodobé citové vazby s turisty, zaměřuje se tato studie na štěstí návštěvníků ve vinařské oblasti Morava $v$ kontextu loajality. Na ukazatele štěstí má vliv celkem sedm věrnostních faktorů: kvalita vína, relaxace, informace o víně, prírodní zajímavosti, přátelské přijetí místními obyvateli, vinařská kultura a tradice i exkurze po vinici. Tato studie dále potvrzuje závislost vnímání štěstí na charakteristikách návštěvníků, jako je pohlaví, príijem nebo s kým navštívili destinaci. Výsledky studie mohou být využity pro znovunastartování a podporu rozvoje udržitelného cestovního ruchu v regionech.
\end{abstract}

Klíčová slova: štěstí návštěvníků, loajalita, vinařská turistika, rozvoj venkova, Česká republika

\title{
Highlights:
}

- Visitors' happiness and loyalty have a rising tendency in a way to contribute to the development of rural areas and their destinations in the tourism context.

- Happiness influences perceived quality, tourist satisfaction, loyalty, and the tourists' behavioral intentions.

- Features of wine tourism such as the quality of wine, surrounding nature (landscape), as well as relaxation, made visitors happy.

- Loyalty factors are specific to wine regions and influence the visitors' happiness.

- Happiness perception depends on specific features and parameters of the destination, which can be used by service providers to secure loyal visitors, who are indispensable, especially during the COVID-19 era.

\section{Introduction}

Considering the current pandemic situation, the heavy competition among service providers in the tourism sector, and the fact that marketing costs of attracting loyal visitors are lower than attracting first-time visitors, attracting a sufficient number of potential visitors became inevitable. This can be reached either by creating and shaping positive relationships with tourists (Ekinci, 2003) or by maintaining and further developing visitors' loyalty (Mendes et al., 2010).

Therefore, it is crucial to focus on the various factors that can lead to visitors' loyalty (Lau and McKercher, 2004). Several factors influence loyalty, such as visitors' satisfaction (Forgas-Coll et al., 2012; Mendes et al., 2010; Štumpf et al., 2019), the uniqueness of the destination (Usakli and 
Baloglu, 2011), safety and political stability (Zhang et al., 2017), and destination image (Chi and $\mathrm{Qu}, 2008)$. Nevertheless, none of these factors solely focus on the visitors' emotions and feelings. They can be however reflected by the visitors' happiness, which Karavdic and Baumann (2014) perceive as a presence of positive emotions and a lack of negative ones.

According to McCabe and Johnson (2013), tourism is one of the main determinants of overall life satisfaction and happiness. On the other hand, visitors' happiness substantially contributes to the formation of the tourists' experiences (Nawijn, 2011), memories (Tung and Ritchie, 2011), and the decision to visit a certain destination (Hart et al., 2009). Unfortunately, there are only a few studies that deal with tourist happiness perception (Bimonte and Faralla, 2012; Bloom et al., 2016; Filep and Deery, 2010; Nawijn et al., 2010; Nawijn, 2011).

Despite this data, some studies, e.g., Bimonte and Faralla (2012), Gillet et al. (2016), and Voigt et al. (2010) confirm the disparity of visitors' happiness perception at different types of destinations. Therefore, this paper focuses on happiness perception and its impact on visitors' loyalty in rural surroundings, more specifically, wine destinations. According to Flamik's (2020) exploration of the subjective perception of quality of life, the residents of wine regions are happier than their fellow citizens from other parts of the country. Compared to other types of destinations, wine destinations respect sustainable development as well as represent current environmental trends (Karagiannis and Metaxas, 2020; Králiková and Kubát, 2020).

Increasing demand for wine tourism by Czech visitors is emerging due to a phenomenon of cult wine and gastronomy services connected with wine. The term "wine tourism destination" may be defined "as a region that bases some or all of its appeal on wineries and wine-related benefits" (Šíp et al. (2018). Tourists in wine destinations seek more than to simply purchase wine. They crave various attractions (cultural, recreational, amusement options), culinary offerings, as well as picturesque, rural, and natural wine landscapes (Getz and Brown, 2006b). Mounting interest in the development of wine tourism destinations and the necessity for better positioning have been presented in various research projects (Bruwer et al., 2016; Hall et al., 2000; Williams, 2001). Furthermore, wine is frequently identified by its geographical origin (e.g., Champagne) and destinations are mostly promoted by their regionally specific attraction. Consequently, the relationship between tourism and wine is extremely significant at the regional level, through the contribution that provides product branding, place promotion, and perception of the destination (Foret et al., 2014). Therefore, tourism is essentially about the difference of places, while wine is a rare commodity that is indicated based on geographical origin (Hall et al., 2000). As noted by Hall and Jenkins (1998), "tourism offers many prospects for rural areas such as employment and income opportunities, often repeatedly utilizing the same resources and possessing the potential to conserve rather than destroy assets."

Tourism and wine have long been perceived as separate entities and unrelated industries, not only in European wine countries but also in wine countries beyond European borders. Thus, wine tourism and its recognition as a significant element in rural tourism have been isolated in wineproducing countries (Hall and Macionis, 1998). At the beginning of wine tourism's development, winemakers themselves and large wineries in the Czech Republic played a very specific role between 1990 and 2000 (Flamik, 2014). Wine tourism services are spread and offered, especially in the Moravia wine region, as it is considered the main wine region suitable for growing, processing, and selling wine together with local cultural traditions (Šíp et al., 2018). This wine region is mostly situated within the South Moravian Region as an administrative unit of the Czech Republic (captured in Figure 1). Compared to other Czech regions, the South Moravia region was the second most visited region by domestic tourists in 2020 (the first being the capital Prague), and the third for incoming tourism (Czech Statistical Office, 2021). Its significance is also given by the predisposition of vineyards, which account for $93.7 \%$ of the total registered vineyards in the country (ČSÚ, 2021). The connection between wine tourism and historically shaped cultural traditions in this region can be considered as a basis of the regional tourism product (Šíp et al., 2018). Furthermore, Foret et al. (2014) emphasize more positive trends in wine tourism development in the Moravia wine region. 


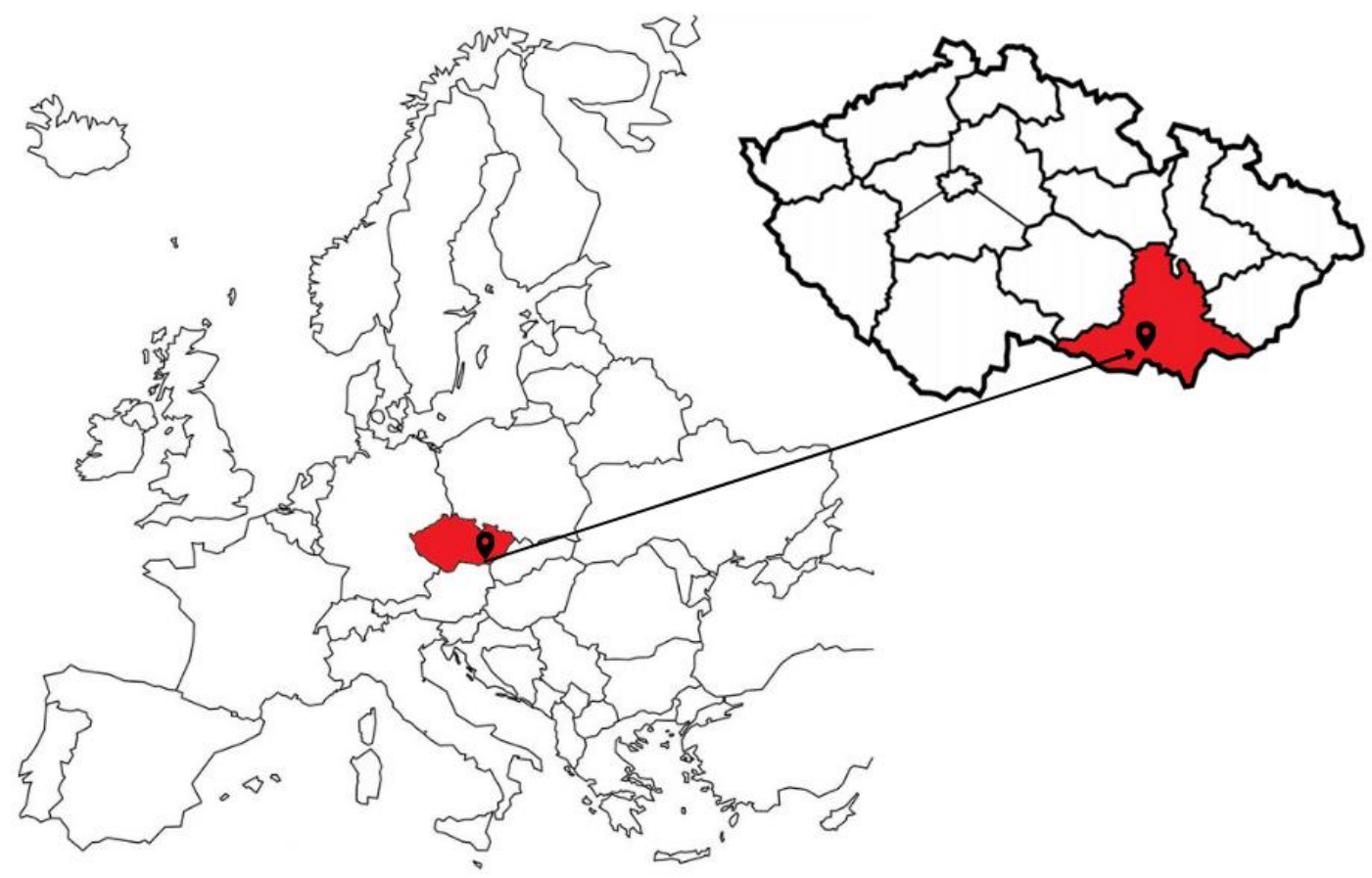

Fig 1. The area under study. Source: Own Editing by Canva.com, 2021

The commencement of wine production in today's Moravia wine subregion territory dates back to the $3^{\text {rd }}$ century, to the days of the Roman Empire. Wine has been produced in the Czech lands for more than twenty centuries, thus making it one of the oldest in Europe (Kraus, 1999). Wine production was mainly oriented on the wine production quantity, similar to other European countries - Serbia, Slovakia, Slovenia, Romania, etc. (Buzalka, 2013; Hall at el., 2000; Hudelson, 2014; Kerma and Gačnik, 2015; Kubát, 2021). The transition from quantity to quality started after the 1990s (Prokeš, 2019). Private entrepreneurship subjects of winemakers were established and started to invest in wine tourism services, even expanding them by their own accommodation facilities (Šíp et al., 2018). This environment began to open up with the establishment of the Moravian Wine Trails project (which was created between 1999-2003) and the activities of the Wine Fund and the National Wine Center. Other impulses were the introduction of modern technologies and marketing activities into the wine trade, together with the deep roots of wine culture and wine tradition in the area (Flamik, 2014). Moravian Wine Trails is a long-term project, whose goal is to protect the cultural heritage and further develop wine tourism in South Moravia. It stretches on a $1,200 \mathrm{~km}$ long network of cycling routes connected into ten circuits, named after the original wine regions, which is connected by the $289 \mathrm{~km}$ long backbone Moravian Wine Trail (Nadace Partnerství, 2021b). A significant impulse for increasing the quality of services, emerging alongside the Moravian Wine Trails, was the certification system, Cyclists Welcome, introduced in 2005 (Nadace Partnerství, 2021a).

Furthermore, various wine tourism activities enable the formation of strong and lasting emotional, as well as social, ties between the particular wine destination and its visitors (Getz and Brown, 2006a; Králiková, 2020; Pelegrín et al., 2019). Additionally, these strong ties might have a substantial impact on revisiting intention (Chen and Tsai, 2007). However, many wine regions competing for wine tourists continue to expand, as does the need to be clearly and uniquely positioned in the minds of their potential visitors (Williams, 2001). On that account, the choice of wine destinations for this paper is felicitous due to the presented emerging emotional, rural, and landscape components, food and wine tourism services/offers, as well as recreation and other visitor motivations. For this reason, the aim of this paper lies in the visitors' happiness perception in the Moravian wine region. 


\section{Theoretical background}

Generally speaking, loyalty is a well-known and extensively researched concept that possesses multiple benefits. For example, better predictability of tourist behavior (Chi and Qu, 2008), lower marketing costs for attracting loyal visitors (Cossío-Silva et al., 2019), and seasonality oppression (Meleddu et al., 2015). Moreover, loyal visitors spend less time planning their visit (Li et al., 2008), they participate more intensively in various tourist activities (Lehto et al., 2004), spend more money on tourism services (Moore et al., 2017), spend more time at the destination, and are keener on recommending the destination (Lau and McKercher, 2004).

In the context of tourism, Hultman et al. (2015) define destination loyalty as a degree of visitors' commitment to the particular destination. On the other hand, Su et al. (2011) define destination loyalty from a psychological point as a socio-psychological structure that influences tourists' cognition, emotions, as well as behavior. Furthermore, individuals' emotions and feelings are a major part of tourist behavior and the decision-making process (Decrop, 1999). According to authors like Yang et al. (2011) or Mason and Paggiaro (2012), visitors' emotions have an impact on satisfaction with the given destination, which can consequently affect visitors' loyalty. Similarly, Yoon and Uysal (2005) observed that positive emotions might lead to a higher probability of recommendation by the visitors. Contrastingly, negative emotions might lead to complaints. Therefore, paying closer attention to tourists' emotions, especially the positive ones, is inevitable.

These positive emotions, such as joy or interest, are not only important during the actual visit of the destination but also before and after the visit of the particular destination (Filep and Deery, 2010; Graburn, 2001). Moreover, building emotional ties with the destination might help DMOs (Destination Management Organisations) to distinguish themselves from their competition (Marzano and Scott, 2009). Visitors with these strong emotional ties are also keener on recommending the destination to their friends and family (Lee et al., 2005).

In the context of a tourist's emotions, happiness can be defined as an individual's emotional feeling of wanting more (Lyubomirsky and Tucker, 1998). Furthermore, Fordyce (1972, p. 227) defined happiness as "a particular emotion, an overall evaluation made by the individual in accounting all their pleasant and unpleasant experiences in the recent past." Recent studies perceive happiness as a presence of positive emotions and the lack of negative ones (Karavdic and Baumann, 2014).

Generally, there are two main directions in tourists' happiness research. One is looking at tourist happiness from the point of subjective well-being and the second one explores the tourist happiness from the authentic happiness side (Veenhoven, 2004). According to Wu (2010), the former looks at the tourist happiness in terms of feeling good, the latter in terms of feeling good as well as deriving meaning from life.

Moreover, according to Han and Back (2007) happiness influences visitors' satisfaction and their behavior at the destination. Also, Glatzer (2000) found that happiness is quite closely linked to satisfaction in the leisure travel sector and is an antecedent of behavioral intentions (Pappas et al., 2013). In addition, Khan and Hussain (2013) proved the influence of happiness on customers' loyalty, and $\mathrm{Li}$ and Petrick (2010) propose that there is a substantial relationship between happiness and quality as well as satisfaction. By taking all of this into consideration, happiness plays a vital role in the aggregation of tourists' behavioral intentions (Prayag et al., 2013).

As of now, tourism studies have not yet identified factors that might determine the perception of tourists' happiness at a particular destination. Nonetheless, some empirical studies confirm that tourists' happiness differs regarding the various specifications of a given destination (Bimonte and Faralla, 2012; Gillet et al., 2016). Therefore, this study is focusing on wine destinations that possess some specific features compared to other types of destinations. As mentioned by Croce and Perri (2017), a relationship between the visitor and the physical environment can be more powerful in wine tourism compared to other types of tourism. Moreover, they clarify an area that wine tourists seek for and travel to, as a physical and geographical area that is confined by the cru, a high-quality vineyard that grows in a certain area and from which is obtained a (particularly excellent) wine. Once at a wine destination, a visitor experiences aspects of this area just as touches of essential concepts of terroir, milieu, region, and landscape. In fact, these concepts 
bring together aspects of wine tourism (destination) - geographic, economic, sociological, and anthropological. Additionally, as with the other above-mentioned concepts, terroir can prefigure crucial assistance in the transformation of an area into a wine tourist destination.

Moreover, several authors are persuaded that wine tourism can play a crucial role in rural tourism as well as the whole regional development (Foret et al., 2014). One of the first definitions of wine tourism was introduced by Hall and Macionis (1998, p. 197): "Wine tourism can be defined as visitation to vineyards, wineries, wine festivals and wine shows for which grape wine tasting and/or experiencing the attributes of a grape wine region are the prime motivating factors for visitors." This also contributes to the revival of the countryside and the protection of the traditional rural landscapes (Scherrer et al., 2009).

Additionally, Bruwer et al. (2013a) observed from a wine tourism perspective that wine tourists who are experiencing wine tourism destinations express positive emotions due to the pleasing physical and natural aspects of the landscapes around the wineries. These positive emotions deriving from services in a destination or winery increase tourists' satisfaction, which subsequently generates positive emotions that influence their future visits and implies a higher number of loyal visitors (Pelegrín et al., 2019; Yuan et al., 2008). As Charters et al. (2009) point out, emotions generated by satisfaction during the winery or wine destination visit can ease the negative emotions.

\section{Methodology}

This paper deals with the impact of loyalty on visitors' happiness in the context of the Moravian wine region. On that account, the primary data among the Czech visitors of the Moravian wine region (the main and largest wine region in the Czech Republic) have been obtained. As a result of COVID-19 restrictions, the observed data were collected only via an online questionnaire in May and June 2020. Moreover, quota sampling based on gender and age was applied. The total number of respondents that visited one of the Moravian subregions in the last five years is 345 and the sample structure of respondents can be seen in Table 1 below.

Tab 1. Sample structure. Source: Own processing

\begin{tabular}{|l|c|c|}
\hline Category of respondents & Absolute number & Relative number (\%) \\
\hline Men & 158 & 45.8 \\
\hline Women & 187 & 54.2 \\
\hline $18-23$ years old & 60 & 17.4 \\
\hline $24-30$ years old & 53 & 15.4 \\
\hline $31-40$ years old & 64 & 18.6 \\
\hline $41-50$ years old & 56 & 16.2 \\
\hline $51-60$ years old & 46 & 13.3 \\
\hline $61-70$ years old & 33 & 9.6 \\
\hline Over 71 years old & 33 & 9.6 \\
\hline
\end{tabular}

Since the paper deals with the Moravian wine region, it is also necessary to know which particular subregion the respondents visited. Therefore, Table 2 shows the number of respondents who visited one of the four Moravian wine subregions (Figure 2) in the last five years.

Approximately, $41 \%$ of respondents visited the Mikulov subregion. Although, it is the smallest Moravian subregion regarding the number of wine villages (in 2019, there were 30 wine villages 
in the Mikulov subregion, 70 in the Velké Pavlovice subregion, 90 in the Znojmo subregion, and 118 in the Slovácko subregion). However, in terms of vine-growing area, it is the largest wine region in the Czech Republic (Bublíková, 2020; HledamVino.cz, 2018). Some of the most visited attractions in The South Moravian Region are also located here. According to CzechTourism (2020), Aqualand Moravia, followed by the Lednice-Valtice landscape, which is registered as a UNESCO World Heritage Site, were the most visited attractions in the South Moravian Region. Furthermore, Svatý Kopeček (Holy Hill) in Mikulov (pilgrimage site) is also in the top 10 South Moravian attractions. Mikulov also hosts one of the most famous Czech vintage events - Pálava Vintages. On the other hand, the second largest city of the Czech Republic, Brno, with its many attractions as well as the wine village Velké Bílovice with 680 wine cellars, lie in the Velké Pavlovice subregion. Hence, the respondents mostly visited these two subregions.

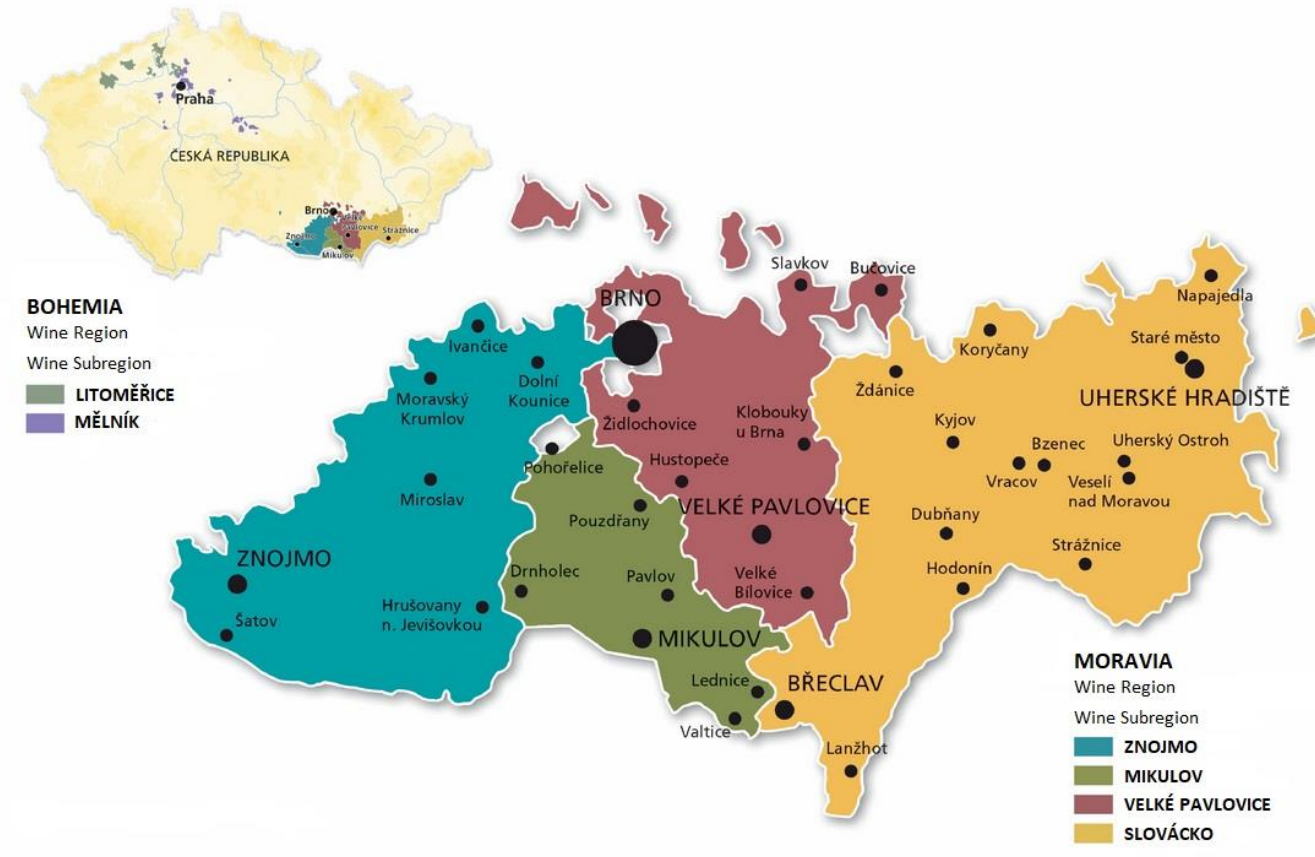

Fig 2. Wine regions in the Czech Republic. Source: HledamVino.cz, 2018

Tab 2. Subregions visited by respondents in the last five years. Source: Own processing

\begin{tabular}{|l|c|c|}
\hline Wine subregion & Absolute number of respondents & Relative number of respondents (\%) \\
\hline Mikulov & 141 & 40.9 \\
\hline Velké Pavlovice & 96 & 27.8 \\
\hline Znojmo & 57 & 16.5 \\
\hline Slovácko & 51 & 14.8 \\
\hline
\end{tabular}

Based on the previous studies (Bruwer et al., 2013a, 2013b, 2016; Byrd et al., 2016; Cohen and Ben-Nun, 2009; Getz and Brown, 2006a; Králiková and Kubát, 2020; Ryglová et al., 2017), 17 loyalty factors were identified. All these factors are presented in Table 3 . On the other hand, the visitors' happiness was evaluated based on two happiness indicators proposed by De Keyser and Lariviere (2014) and Theodorakis et al. (2014) as well as the open-ended question: "What made visitors happy in a Moravian wine region?". The first happiness indicator being the stay at the destination made visitors happy and the second being the stay at the destination contributed to visitors' happiness. Both loyalty factors and happiness indicators were evaluated on a five-point Likert scale (the number 5 representing "strongly agree with the given statement"). 
Hence, the multiple regression analyses using the OLS (Ordinary Least Square) method have been used to identify the loyalty factors that impact the visitors' happiness (Nunkoo and Ramkissoon, 2012). Consequently, due to the ordinality and non-normality of the data, the Kruskal-Wallis test was used to evaluate the dependence of visitors' personal characteristics (e.g., income or gender) on their happiness perception (Laerd statistics, 2018). The null hypothesis for this test assumes the same distribution for the given personal characteristics (Sheskin, 2011).

\section{Results}

Table 3 shows 17 loyalty factors that were examined in this study, following the significance for the visitors of the Moravian wine region, measured by the average values. Hence, the most significant loyalty factor is the quality of wine, followed by the natural attractions, wine tasting, and relaxation. This is a particularly positive sign as these factors might be, at least to some extent, controlled by the winery itself.

Tab 3. Loyalty factors. Source: Own processing

\begin{tabular}{|l|c|c|c|}
\hline Factor & Mean & Median & Std. dev. \\
\hline Quality of wine & 4.316 & 5.0 & 0.972 \\
\hline Natural attractions & 4.310 & 5.0 & 1.075 \\
\hline Wine tasting & 4.181 & 5.0 & 1.101 \\
\hline Relaxation & 4.129 & 4.0 & 1.110 \\
\hline Friends & 3.999 & 4.0 & 1.209 \\
\hline Wine culture and traditions & 3.971 & 4.0 & 1.099 \\
\hline Wine events & 3.839 & 4.0 & 1.177 \\
\hline Wine purchase & 3.677 & 4.0 & 1.232 \\
\hline Information about wine & 3.651 & 4.0 & 1.141 \\
\hline Vineyard excursion & 3.638 & 4.0 & 1.191 \\
\hline Friendly acceptance by the locals & 3.619 & 4.0 & 1.116 \\
\hline Cultural monuments & 3.599 & 4.0 & 1.215 \\
\hline Traveling & 3.549 & 4.0 & 1.227 \\
\hline Winery & 3.542 & 4.0 & 1.226 \\
\hline Social interaction & 3.425 & 4.0 & 1.181 \\
\hline Gastronomy & 3.333 & 3.5 & 1.234 \\
\hline Transport accessibility & 2.716 & 3.0 & 1.214 \\
\hline
\end{tabular}

On the other hand, the least important loyalty factor in the Moravian wine region is transport accessibility. That might be caused by the rather short distance between various wineries in wine villages as well as the project Moravian Wine Trails, which provides regionally densely spread cycling routes through the landscape and vineyards of South Moravia (Nadace Partnerství, 2021b). As the transport accessibility is quite high in this region and the Moravian Wine Trails are well known among domestic visitors, they don't pay that much attention to this loyalty factor. It can be seen as a basic prerequisite for visiting a winery or wine region through the provided 
routes, paths, and infrastructure, and therefore it does not play an important role in the minds of visitors.

If we look at the happiness indicators, respondents were distinctly happy in the Moravian wine region, as the median of both indicators is four (on a five-point Likert scale). Moreover, Table 4 shows the results of the dependence analysis of happiness indicators on various respondent characteristics. Both gender and income have an impact on all happiness indicators - the stay at the destination made visitors happy and it also contributed to their happiness. In each case, women evaluated happiness indicators higher than men. Furthermore, those respondents with a monthly income lower than 30,000 CZK are happier in the Moravian wine region compared to the visitors with higher incomes. On the other hand, the frequency of visits and with whom tourists visited the destination only influences one happiness indicator: the stay in the destination contributed to their happiness. Regarding the frequency of visits, those who visit the Moravian wine region and its wine events more than three times per year are happier. Furthermore, tourists who visited the destination with their partners were happier as well.

Tab 4. Dependence analysis. Source: Own processing

\begin{tabular}{|l|r|r|r|r|r|r|c|}
\hline Factor & Mean & Median & $\begin{array}{c}\text { Std. } \\
\text { dev. }\end{array}$ & $\begin{array}{c}\text { KW test } \\
\text { gender }\end{array}$ & $\begin{array}{c}\text { KW test } \\
\text { income }\end{array}$ & $\begin{array}{c}\text { KW test } \\
\text { frequency } \\
\text { of visit }\end{array}$ & $\begin{array}{c}\text { KW test } \\
\text { with whom } \\
\text { they visited }\end{array}$ \\
\hline Made happy & 4.125 & 4.0 & 1.011 & YES+ & YES+ & NO & NO \\
\hline $\begin{array}{l}\text { Contributed to } \\
\text { happiness }\end{array}$ & 4.003 & 4.0 & 1.047 & YES+ & YES & YES+ & YES \\
\hline
\end{tabular}

Note:

YES $+\rightarrow$ dependence of the given variable on the particular respondents' characteristics was proven at $5 \%$ significance level.

YES $\rightarrow$ dependence of the given variable on the particular respondents' characteristics was proven at $10 \%$ significance level.

NO $\rightarrow$ dependence of the given variable on the particular respondents' characteristics was not proven.

In order to explore the influence of loyalty factors on the happiness indicators, a regression analysis was performed. The results can be seen in Table 5 and Table 6 . The constant represents the value of a dependent variable (in our case Made Happy and Contributed to Happiness variable) when all independent variables would equal zero in any period of time. Furthermore, the list is ordered by their influence, beginning with the most influential loyalty factor. Consequently, seven loyalty factors have an impact on the happiness indicators. In particular, five factors (relaxation, natural attractions, quality of wine, friendly acceptance by the locals, and information about wine) have been statistically significant for both indicators. On the other hand, wine culture and the traditions factor influence only made the happy indicator and the vineyard excursion influence solely contributed to the happiness indicator.

Tab 5. Regression analysis - the stay at the destination made visitors happy. Source: Own processing

\begin{tabular}{|l|c|c|}
\hline \multicolumn{1}{|c|}{ Made happy } & Regression coefficient & P-value \\
\hline Constant & 1.070 & $5.89 \mathrm{e}-06$ \\
\hline Relaxation & 0.162 & $3.10 \mathrm{e}-03$ \\
\hline Natural attractions & 0.139 & $1.50 \mathrm{e}-02$ \\
\hline Quality of wine & 0.136 & 0.025 \\
\hline Friendly acceptance by the locals & 0.112 & 0.0166 \\
\hline Wine culture and traditions & 0.110 & 0.0475 \\
\hline Information about wine & 0.097 & $3.91 \mathrm{e}-02$ \\
\hline
\end{tabular}

Note: $\mathrm{R}^{2}=0.354 ; \mathrm{R}^{2}$ adj. $=0.343 ; 5 \%$ significance level. 
Tab 6. Regression analysis - the stay at the destination contributed to visitors' happiness. Source: Own processing

\begin{tabular}{|l|c|c|}
\hline Contributed to happiness & Regression coefficient & P-value \\
\hline Constant & 0.920 & $2.00 \mathrm{e}-04$ \\
\hline Relaxation & 0.184 & $1.30 \mathrm{e}-03$ \\
\hline Quality of wine & 0.151 & $1.68 \mathrm{e}-02$ \\
\hline Natural attractions & 0.146 & 0.0152 \\
\hline Information about wine & 0.101 & 0.0461 \\
\hline Friendly acceptance by the locals & 0.097 & 0.0448 \\
\hline Vineyard excursion & 0.089 & $6.41 \mathrm{e}-02$ \\
\hline
\end{tabular}

Note: $\mathrm{R}^{2}=0.333 ; \mathrm{R}^{2}$ adj. $=0.321 ; 5 \%$ significance level.

The results of the regression analysis are also in line with the answers to the open-ended question of "What makes the visitors happy in the Moravian wine region?". The complete list of the answers can be seen in Figure 3. The larger the text in the picture, the more frequently the particular characteristic was mentioned by the respondents. Hence, the most frequently mentioned characteristics by respondents were wine (almost $24 \%$ ), mostly the quality of wine, followed by the nature surrounding the vineyards (nearly $18 \%$ ), as well as the relaxation (16\%).

All of these characteristics are specific to the wine region and can therefore be altered and influenced not only by the various DMOs in the region but also by the wineries, winemakers, and, to some extent, by tourists as well (Cohen and Ben-Nun, 2009; Mendes et al., 2010; Prayag et al., 2013). Hence, it is inevitable to pay closer attention to the quality of wine, relaxation opportunities for visitors, as well as the cultivation of the nature surrounding the vineyards, as they highly contribute to the visitors' happiness. Furthermore, happy visitors might be more satisfied (Li and Petrick, 2010) and loyal (Khan and Hussain, 2013) to the Moravian wine region, which is a particularly desirable outcome, especially in times when the COVID-19 restrictions may curtail wine tourism activities.

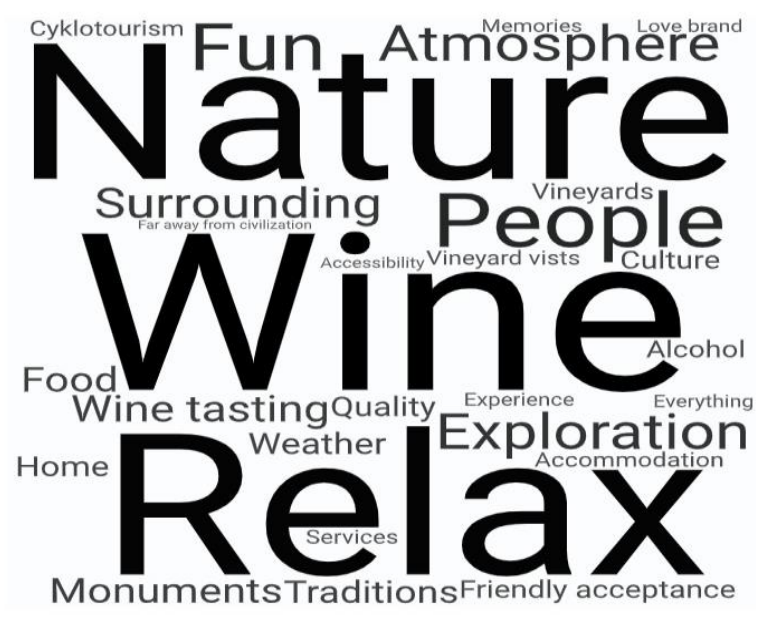

Fig 3. What makes visitors happy? Source: Own Editing by Wordart.com, 2021

\section{Discussion}

Overall, the happiness perception is influenced by genetics (explains up to $50 \%$ of variability), life situation (up to $10 \%$ of variability), and current activities (up to $40 \%$ of variability), such as working, exercising, or traveling (Shah and Marks, 2004). Therefore, demographic factors like age, gender, income, or marital status can influence the happiness perception (Neal et al., 1999). This research confirmed the dependence of both the 'made happy' and 'contributed to happiness' indicators on the gender and income of the respondents. Furthermore, the dependence of 'contributed to happiness' on the frequency of visits as well as with whom respondents visited the Moravian wine 
region was confirmed. This supports the findings of Diener and Biswas-Diener (2008), who found that not only visitors' happiness but also their satisfaction is influenced by the feelings of other people with whom the tourist is traveling. In the case of the Moravian wine region, those who visited a certain subregion with their partner were happier. Moreover, those with a lower income were also happier than those with a higher income. That might be caused by the lower perception of relaxation opportunities and wine quality by the higher-income respondents. Therefore, it would be beneficial to focus more on these two loyalty factors, in the case of wineries that are aiming at the higher income clientele, to ensure a high level of visitors' happiness.

A higher level of perceived happiness at the destination could potentially lead to a strong emotional tie with the destination. According to Marzano and Scott (2009), that might help a certain destination to distinguish itself from other competitors, and the visitors might be more inclined to recommend this specific destination to their friends and family (Lee et al., 2005). As the visitors of the Moravian wine region are generally very happy (median was four for both happiness indicators) and almost $60 \%$ of respondents prefer a long-term experience connected to the visit to a wine destination, we can confirm the observation made by Getz and Brown (2006a), that various activities of wine tourism can help to build long-term social and emotional ties between visitors and certain destinations, and that happiness might substantially contribute to these ties. They might also result in a favorable image of the particular wine destination, which can then, according to Chen and Tsai (2007), help with the final destination choice.

Nevertheless, in the process of wine destination choice, other factors like destination quality may be considered. In their study, Št'astná et al. (2020) point to quality factors within the vine-growing destination and, similarly to this paper, confirm the factor wine quality as the most significant for the wine destination visitors. Another research by Pelegrín et al. (2019) dealing with emotions produced by the wine, specifies that tourists' emotions differ based on their cause. They emphasize that the emotions produced by the wine offer had the strongest influence on the intention to purchase that particular wine. Therefore, for visitors to be happier and show greater positive emotions, their presence in the destination is required, preferably in the winery, where they can buy regional wine, thus confirming their greater loyalty to the destination as well as the winery. In addition, Pelegrín et al. (2019) results confirmed that the positive emotions produced by wine had a positive influence on purchase intent.

Furthermore, happiness has an impact on the tourists' experience (Nawijn, 2011), satisfaction (Han and Beck, 2007), loyalty (Khan and Hussain, 2013), as well as the decision to visit a particular destination (Hart et al., 2009). This is also evident from the results of this paper, where the higher the perceived visitors' happiness is, the higher the average value of variables: revisit and recommendation intention, satisfaction level as well as enjoying traveling. This can be seen in Figure 4, where the x-axis represents the perceived visitors' happiness (value of Made Happy and Contributes to Happiness variables). On the other hand, the y-axis represents an average value of satisfaction and loyalty indicators at a given happiness level.
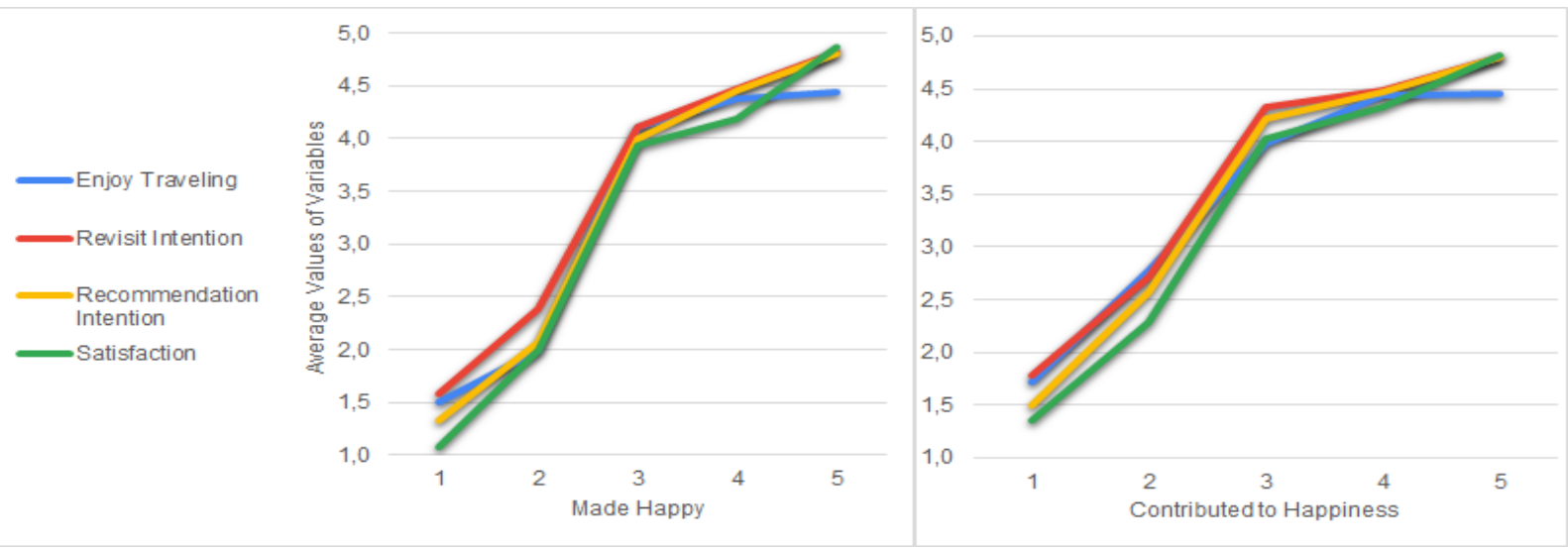

Fig 4. Impact of Happiness. Source: Own processing

Note: 1 - strongly disagree with a given statement, 5 - strongly agree with a given statement 
Hence, the various wineries, as well as DMOs, should also pay attention to the happiness of their visitors. Especially, to the factors they can control and potentially influence the happiness perception in the wine region. Based on the regression analysis, importance evaluation, and Št'astná et al. (2020), those factors are natural attraction, relaxation, quality of wine, information about wine, wine culture and traditions, vineyard excursions, and friendly acceptance by the locals.

On the other hand, this study presents factors like transportation (local, regional), infrastructure, and cultural attractions/monuments to be of low priority for visitors. These findings are also confirmed by Št'astná et al. (2020). Therefore, supply-side actors in a particular destination or region don't need to pay that much attention to them. They should rather concentrate their financial resources on previously mentioned key factors to ensure the growth of visitors' happiness, satisfaction, as well as for the development of a rural area, including a wine destination.

Moreover, according to Bimonte and Faralla (2012), park visitors are happier than beach visitors, the stay in different types of spas causes rather positive emotions (Voigt et al., 2010), a similar situation is with holidays connected to diving activities (Kler and Tribe, 2012), or while engaging in experiential activities such as mountain climbing (Tsaur et al., 2013). In addition, tourists experience a greater level of happiness and joy when they reach a higher level of personal identification with a given activity, within the context of sports tourism (Bosnjak et al., 2016). The same applies to participation in more demanding activities, where the tourists have to rely more on their knowledge and skills (Csikszentmihalyi, 1990).

Given that the above mentioned seven loyalty factors in Table 5 and 6 , with some significant factors (information about wine, relaxation, and vineyard excursion) that have a great impact on happiness perception as well as the answers to the open-ended question, "What makes visitors happy?", are largely dependent on the wine tourism. Therefore, we can confirm the observations made by Voigt et al. (2010), Bimonte and Faralla (2012), Tsaur et al. (2013), and Gillet et al. (2016), that there are differences in the happiness perception based on different types of destinations.

\section{Conclusions}

The main goal of this paper was to examine visitors' happiness concerning loyalty perception in the main Czech wine region of Moravia. Overall, seven loyalty factors influence the happiness indicators. Namely, the factors include: quality of wine, relaxation, information about wine, natural attractions, friendly acceptance by the locals, wine culture and traditions, as well as vineyard excursion. These results also support the findings from the open-ended question of "What makes people happy in the wine destination?". All of these factors are closely related to the Moravian wine region as well as the particular wine cellar. Moreover, these factors can be, to some extent, controlled by the winemakers or the DMOs in this region. Previous studies also found that happiness influences perceived quality (Li and Petrick, 2010), tourist satisfaction (Han and Back, 2007), loyalty (Khan and Hussain, 2013), as well as the tourists' behavioral intentions (Pappas et al., 2013). Therefore, it is inevitable to pay closer attention to the above-mentioned loyalty factors as they are specific to wine regions and might influence the visitors' happiness to a great extent.

Additionally, we also found that the happiness perception depends not only on the specific parameters and features of the destination but also on the personal characteristics of visitors. On that account, more extensive research dealing with tourist happiness is needed. This paper deals only with wine tourism destinations. Hence, future research should focus on other types of destinations as well.

Furthermore, the results enable a better and deeper understanding of visitors' happiness and its connection to loyalty in the Czech wine regions, as an important tourism sector in the country, especially in the Moravian wine region. A particularly positive sign is that the happiness level increased by the number of visits to the particular destination. Moreover, what made visitors mostly happy were some of the crucial features of wine tourism, such as the quality of wine, surrounding nature (landscape), as well as relaxation. Therefore, service providers can use 
the results of this paper to secure loyal visitors, who are indispensable, especially during the COVID-19 era. The results could also be used to better target visitors of wine destinations and the offerings they receive.

However, this paper deals only with loyalty factors. Therefore, it would be suitable to focus on other factors that might influence the visitors' happiness, such as satisfaction or image factors. Since the wine literature base is rising and tourists are discovering new wine places at the same time, a knowledge gap still remains between what wine tourists want at/from wine tourism destination (experience) and what wineries and service providers are able to deliver them.

\section{Acknowledgement}

This research paper was written in collaboration with two projects of the Internal Grant Agency of the Faculty of Business and Economics of Mendel University in Brno (PEF_DP_2021011 and PEF_DP_2021015) in 2021.

\section{Academic references}

[1] Bimonte, S. \& Faralla, V. (2012). Tourist types and happiness: A comparative study in Maremma, Italy. Annals of Tourism Research, 39(4), 1929-1950. DOI: 10.1016/j.annals.2012.05.026.

[2] Bloom, J., Geurts, S. \& Lohmann, M. (2016). Tourism and love: How do tourist experiences affect romantic relationships? In Filep, S., Laing, J. \& Csikszentmihalyi, M., eds., Positive Tourism (pp. 35-53). London: Routledge. DOI: 10.4324/9781315707129.

[3] Bosnjak, M., Brown, C. A., Lee, D. J., Yu, G. B. \& Sirgy, M. J. (2016). Self-expressiveness in sport tourism: Determinants and consequences. Journal of Travel Research, 55(1), 125134. DOI: $10.1177 / 0047287514535845$.

[4] Bruwer, J., Coode, M., Saliba, A. \& Herbst, F. (2013a). Wine tourism experience effects of the tasting room on consumer brand loyalty. Tourism Analysis, 18(4), 399-414. DOI: $10.3727 / 108354213 X 13736372325957$.

[5] Bruwer, J., Gross, M. J. \& Lee, H. C. (2016). Tourism destination image (TDI) perception within a regional winescape context. Tourism Analysis, 21(2-3), 173-187. DOI: $10.3727 / 108354216 \times 14559233984692$.

[6] Bublíková, L. (2020). Situační a výhledová zpráva réva vinná a víno. Praha: Ministry of Agriculture.

[7] Buzalka, J. (2013). Tasting Wine in Slovakia: Postsocialist Elite Consumption of Cultural Particularities. In Black, R. E. \& Ulin, R. C., eds., Wine and Culture: Vineyard to Glass (pp. 89-108). London: Bloomsbury Academic. DOI: 10.5040/9781350042254.ch-005.

[8] Byrd, E. T., Canziani, B., Hsieh, Y. C. J., Debbage, K. \& Sonmez, S. (2016). Wine tourism: Motivating visitors through core and supplementary services. Tourism Management, 52, 19 29. DOI: 10.1016/j.tourman.2015.06.009.

[9] Charters, S., Fountain, J. \& Fish, N. (2009). "You Felt Like Lingering . . .": Experiencing "Real" Service at the Winery Tasting Room. Journal of Travel Research, 48(1), 122-134. DOI: $10.1177 / 0047287508326508$.

[10] Chen, C. F. \& Tsai, D. C. (2007). How destination image and evaluative factors affect behavioral intentions? Tourism Management, 28(4), 1115-1122. DOI: 10.1016/j.tourman.2006.07.007.

[11] Chi, C. G. Q. \& Qu, H. (2008). Examining the structural relationships of destination image, tourist satisfaction and destination loyalty: An integrated approach. Tourism Management, 29(4), 624-636. DOI: 10.1016/j.tourman.2007.06.007. 
[12] Cohen, E. \& Ben-Nun, L. (2009). The important dimensions of wine tourism experience from potential visitors' perception. Tourism and Hospitality Research, 9(1), 20-31. DOI: $10.1057 /$ thr.2008.42.

[13] Cossío-Silva, F. J., Revilla-Camacho, M. Á. \& Vega-Vázquez, M. (2019). The tourist loyalty index: A new indicator for measuring tourist destination loyalty? Journal of Innovation \& Knowledge, 4(2), 71-77. DOI: 10.1016/j.jik.2017.10.003.

[14] Croce, E. \& Perri, G. (2017). Food and wine tourism: integrating food, travel and terroir. $2^{\text {nd }}$ ed. Wallingford: CABI.

[15] Csikszentmihalyi, M. (1990). Flow: the psychology of optimal experience. New York: Harper Perennial.

[16] De Keyser, A. \& Lariviere, B. (2014). How technical and functional service quality drive consumer happiness: Moderating influences of channel usage. Journal of Service Management, 25(1), 30-48. DOI: 10.1108/JOSM-04-2013-0109.

[17] Decrop, A. (1999). Tourists' decision making and behavior processes. In Pizam, A. \& Mansfeld, Y., eds., Consumer behavior in travel and tourism (pp. 103-133). New York: The Haworth Press Inc.

[18] Diener, E. \& Biswas-Diener, R. (2008). Happiness: Unlocking the mysteries of psychological wealth. Oxford: Blackwell.

[19] Ekinci, Y. (2003). From destination image to destination branding: An emerging area of research. E-review of Tourism Research, 1(2), 21-24.

[20] Filep, S. \& Deery, M. (2010). Towards a picture of tourists' happiness. Tourism Analysis, 15(4), 399-410. DOI: 10.3727/108354210X12864727453061.

[21] Fordyce, M. W. (1972). Happiness, its daily variation and its relation to values. [unpublished PhD thesis]. San Diego, CA: U.S. International University.

[22] Foret, M., Konečný, O. \& Klusáček, P. (2014). Viticulture - Challenge for Tourism Development (Znojmo Case Study Area). Acta Universitatis Agriculturae et Silviculturae Mendelianae Brunensis, 62(2), 339-346. DOI: 10.11118/actaun201462020339.

[23] Forgas-Coll, S., Palau-Saumell, R., Sánchez-García, J. \& Callarisa-Fiol, L. J. (2012). Urban destination loyalty drivers and cross-national moderator effects: the case of Barcelona. Tourism Management, 33(6), 1309-1320. DOI: 10.1016/j.tourman.2011.12.013.

[24] Getz, D. \& Brown, G. (2006a). Critical success factors for wine tourism regions: a demand analysis. Tourism Management, 27(1), 146-158. DOI: 10.1016/j.tourman.2004.08.002.

[25] Getz, D. \& Brown, G. (2006b). Benchmarking wine tourism development. International Journal of Wine Marketing, 18(2), 78-97. DOI: 10.1108/09547540610681077.

[26] Gillet, S., Schmitz, P. \& Mitas, O. (2016). The snap-happy tourist: The effects of photographing behavior on tourists' happiness. Journal of Hospitality \& Tourism Research, 40(1), 37-57. DOI: 10.1177/1096348013491606.

[27] Glatzer, W. (2000). Happiness: Classic theory in the light of current research. Journal of Happiness Studies, 1(4), 501-511. DOI: 10.1023/A:1011550727571.

[28] Graburn, N. H. H. (2001). Secular ritual: A general theory of tourism. In Smith, V. L. \& Brent, M., eds., Hosts and guests revisited: Tourism issues of the 21st century (pp. 42-50). Elmsford: Cognizant Communications Corporation.

[29] Hall, C. M. \& Macionis, N. (1998). Wine tourism in Australia and New Zealand. In Butler, R., Hall, C. M. \& Jenkins, J., eds., Tourism and Recreation in Rural Areas (pp. 197-224). Hoboken: John Wiley \& Sons Ltd.

[30] Hall, C. M. \& Jenkins, J. (1998). The policy dimensions of rural tourism and recreation. In Butler, R., Hall, C. M. \& Jenkins, J., eds., Tourism and Recreation in Rural Areas (pp. 1942). Hoboken: John Wiley \& Sons Ltd. 
[31] Hall, C. M., Sharples, L., Cambourne, B. \& Macionis, N., eds. (2000). Wine Tourism Around the World: Development, Management and Markets. Oxford: Butterworth-Heinemann.

[32] Han, H. \& Back, K. J. (2007). Investigating the effects of consumption emotions on customer satisfaction and repeat visit intentions in the lodging industry. Journal of Hospitality \& Leisure Marketing, 15(3), 5-30. DOI: 10.1300/J150v15n03_02.

[33] Hart, W., Albarracín, D., Eagly, A. H., Brechan, I., Lindberg, M. J. \& Merrill, L. (2009). Feeling validated versus being correct: a meta-analysis of selective exposure to information. Psychological Bulletin, 135(4), 555-588. DOI: 10.1037/a0015701.

[34] Hudelson, E. J. (2014). Eastern Promises: The Potential Future for Wine Tourism in the Balkans. American Journal of Tourism Management, 3(1B), 34-50. DOI: 10.5923/s.tourism.201402.05.

[35] Hultman, M., Skarmeas, D., Oghazi, P. \& Beheshti, H. M. (2015). Achieving tourist loyalty through destination personality, satisfaction, and identification. Journal of Business Research, 68(11), 2227-2231. DOI: 10.1016/j.jbusres.2015.06.002.

[36] Karagiannis, D. \& Metaxas, T. (2020). Sustainable Wine Tourism Development: Case Studies from the Greek Region of Peloponnese. Sustainability, 12(12), 5223. DOI: $10.3390 /$ su12125223.

[37] Karavdic, S. \& Baumann, M. (2014). Positive career attitudes effect on happiness and life satisfaction by master students and graduates. Open Journal of Social Sciences, 2, 15-23. DOI: 10.4236/jss.2014.28003.

[38] Kerma, S. \& Gačnik, A. (2015). Wine Tourism as an Opportunity for Tourism Development: Examples of Good Practice in Slovenia. Journal of International Food \& Agribusiness Marketing, 27(4), 311-323. DOI: 10.1080/08974438.2014.940122.

[39] Khan, S. \& Hussain, M. (2013). Determinants of consumer happiness and its role in customer loyalty. International Review of Management and Business Research, 2(1). DOI: 10.2139/ssrn.2269677.

[40] Kler, B. K. \& Tribe, J. (2012). Flourishing through SCUBA: Understanding the pursuit of dive experiences. Tourism in Marine Environments, 8(1-2), 19-32. DOI: $10.3727 / 154427312 X 13262430524027$.

[41] Králiková, A. \& Kubát, P. (2020). Czech wine regions in the context of tourist loyalty. In Soukupová, N., ed., Proceedings of the 14th International Scientific Conference INPROFORUM (pp. 220-225). České Budějovice: University of South Bohemia.

[42] Králiková, A. (2020). Czech Wine Regions in the Context of Visitors' Happiness. In Hampel, D., ed., PEFnet 2020: Abstracts (pp. 99-100). Brno: Mendel University in Brno.

[43] Kraus, V. (1999). Réva a víno v Čechách a na Moravě. Praha: RADIX.

[44] Kubát, P. (2021). Keep The Pace: The Uncorked Potential of Wine Tourism in Šumadija. Balkans Journal of Emerging Trends in Social Sciences, 4(1), 43-53. DOI: 10.31410/Balkans.JETSS.2021.4.1.43-53.

[45] Kubát, P. (2019). Development of wine tourism in Šumadija region. In Hampel, D., ed., PEFnet 2019: Abstracts (pp. 79-80). Brno: Mendel University in Brno.

[46] Lau, A. L. \& McKercher, B. (2004). Exploration versus acquisition: A comparison of first-time and repeat visitors. Journal of Travel Research, 42(3), 279-285. DOI: $10.1177 / 0047287503257502$.

[47] Lee, C. K., Lee, Y. K. \& Lee, B. (2005). Korea's destination image formed by the 2002 World Cup. Annals of Tourism Research, 32(4), 839-858. DOI: 10.1016/j.annals.2004.11.006.

[48] Lehto, X. Y., O'Leary, J. T. \& Morrison, A. M. (2004). The effect of prior experience on vacation behavior. Annals of Tourism Research, 31(4), 801-818. DOI: 10.1016/j.annals.2004.02.006. 
[49] Li, X. \& Petrick, J. F. (2010). Towards an integrative model of loyalty formation: The role of quality and value. Leisure Sciences: An Interdisciplinary Journal, 32(3), 201-221. DOI: 10.1080/01490401003709123.

[50] Li, X., Cheng, C. K., Kim, H. \& Petrick, J. F. (2008). A systematic comparison of first-time and repeat visitors via a two-phase online survey. Tourism Management, 29(2), 278-293. DOI: 10.1016/j.tourman.2007.03.010.

[51] Lyubomirsky, S. \& Tucker, K. L. (1998). Implications of individual differences in subjective happiness for perceiving, interpreting, and thinking about life events. Motivation and Emotion, 22(2), 155-186. DOI: 10.1023/A:1021396422190.

[52] Mason, M. C. \& Paggiaro, A. (2012). Investigating the role of festivalscape in culinary tourism: The case of food and wine events. Tourism Management, 33(6), 1329-1336. DOI: 10.1016/j.tourman.2011.12.016.

[53] Marzano, G. \& Scott, N. (2009). Power in destination branding. Annals of Tourism Research, 36(2), 247-267. DOI: 10.1016/j.annals.2009.01.004.

[54] McCabe, S. \& Johnson, S. (2013). The happiness factor in tourism: Subjective well-being and social tourism. Annals of Tourism Research, 41, 42-65. DOI: 10.1016/j.annals.2012.12.001.

[55] Meleddu, M., Paci, R. \& Pulina, M. (2015). Repeated behaviour and destination loyalty. Tourism Management, 50, 159-171. DOI: 10.1016/j.tourman.2015.01.032.

[56] Mendes, C. J., Oom, P. V., Guerreiro, M. M. \& Silva, J. A. (2010). The tourist experience: Exploring the relationship between tourist satisfaction and destination loyalty. Tourism, $58(2)$, 111-126.

[57] Moore, S. A., Rodger, K. \& Taplin, R. H. (2017). Developing a better understanding of the complexities of visitor loyalty to Karijini National Park, Western Australia. Tourism Management, 62, 20-28. DOI: 10.1016/j.tourman.2017.03.012.

[58] Nawijn, J. (2011). Determinants of daily happiness on vacation. Journal of Travel Research, 50(5), 559-566. DOI: 10.1177/0047287510379164.

[59] Nawijn, J., Marchand, M. A., Veenhoven, R. \& Vingerhoets, A. J. (2010). Vacationers happier, but most not happier after a holiday. Applied Research in Quality of Life, 5(1), 3547. DOI: $10.1007 / \mathrm{s} 11482-009-9091-9$.

[60] Neal, J. D., Sirgy, M. J. \& Uysal, M. (1999). The role of satisfaction with leisure travel/tourism services and experience in satisfaction with leisure life and overall life. Journal of Business Research, 44(3), 153-163. DOI: 10.1016/S0148-2963(97)00197-5.

[61] Nunkoo, R. \& Ramkissoon, H. (2012). Structural equation modelling and regression analysis in tourism research. Current Issues in Tourism, 15(8), 777-802. DOI: $10.1080 / 13683500.2011 .641947$.

[62] Pappas, I. O., Giannakos, M. N., Kourouthanassis, P. E. \& Chrissikopoulos, V. (2013). Assessing emotions related to privacy and trust in personalized services. In Douligeris, C., Pokemi, N., Karantjias, A. \& Lamersdorf, W., eds., Collaborative, trusted and privacy-aware e/m-services (pp. 38-49). Berlin: Springer.

[63] Pelegrín, J., González-Menorca, C. \& Meraz, L. (2019). The influence of the emotions produced by the wine offer, winery visits, and wine news on wine purchase intent in tourists. Spanish Journal of Agricultural Research, 17(1). DOI: 10.5424/sjar/2019171-13524.

[64] Prayag, G., Hosany, S. \& Odeh, K. (2013). The role of tourists' emotional experiences and satisfaction in understanding behavioral intentions. Journal of Destination Marketing \& Management, 2(2), 118-127. DOI: 10.1016/j.jdmm.2013.05.001.

[65] Prokeš, M. (2019). Wine trails in the Czech Republic. In Sigala, M. \& Robinson, R., eds., Wine tourism destination management and marketing: theory and cases (pp. 341-355). London: Palgrave Macmillan. DOI: 10.1007/978-3-030-00437-8. 
[66] Ryglová, K, Rašovská, I. \& Šácha, J. (2017). Rural Tourism-Evaluating the Quality of Destination. European Countryside, 9(4), 769-788. DOI: 10.1515/euco-2017-0043.

[67] Shah, H. \& Marks, N. (2004). A well-being manifesto for a flourishing society. London: New Economics Foundation.

[68] Scherrer, P., Alonso, A. \& Sheridan, L. (2009). Expanding the destination image: wine tourism in the Canary Islands. International Journal on Tourism Research, 11(5), 451-463. DOI: $10.1002 /$ jtr.713.

[69] Sheskin, D. J. (2011). Handbook of parametric and nonparametric statistical procedures, $5^{\text {th }}$ ed. Boca Raton: Chapman and Hall/CRC.

[70] Su, H. J., Cheng, K. F. \& Huang, H. H. (2011). Empirical study of destination loyalty and its antecedent: The perspective of place attachment. The Service Industries Journal, 31(16), 2721-2739. DOI: 10.1080/02642069.2010.511188.

[71] Šíp, J., Ryšková, J. \& Smrčka, F. (2018). Territorial Connections of Wine Tourism to Vine Growing and Wine Produce in The Winegrowing Sub-Regions of Slovácko and Znojemsko. Czech Hospitality \& Tourism Papers, 14(30), 16-27.

[72] Št’astná, M., Vaishar, A., Ryglová, K., Rašovská, I. \& Zámečník, S. (2020). Cultural Tourism as a Possible Driver of Rural Development in Czechia. Wine Tourism in Moravia as a Case Study. European Countryside,12(3), 292-311. DOI: 10.2478/euco-2020-0017.

[73] Štumpf, P., Vojtko, V. \& Janeček, P. (2020). Do European tourists intend to revisit the same countries? Effect of satisfaction in European Union destinations. Scandinavian Journal of Hospitality and Tourism, 20(4), 398-417. DOI: 10.1080/15022250.2020.1807405.

[74] Theodorakis, N. D., Kaplanidou, K. \& Karabaxoglou, I. (2014). Effect of event service quality and satisfaction on happiness among runners of a recurring sport event. Leisure Sciences: An Interdisciplinary Journal, 37(1), 87-107. DOI: 10.1080/01490400.2014.938846.

[75] Tsaur, S.-H., Yen, C.-H. \& Hsiao, S.-L. (2013). Transcendent experience, flow and happiness for mountain climbers. International Journal of Tourism Research, 15(4), 360-374. DOI: 10.1002/jtr.1881.

[76] Tung, V. W. S. \& Ritchie, J. B. (2011). Exploring the essence of memorable tourism experiences. Annals of Tourism Research, 38(4), 1367-1386. DOI: 10.1016/j.annals.2011.03.009.

[77] Usakli, A. \& Baloglu, S. (2011). Brand personality of tourist destinations: An application of self-congruity theory. Tourism Management, 32(1), 114-127. DOI: 10.1016/j.tourman.2010.06.006.

[78] Veenhoven, R. (2004). Happy Life Years: A measure of Gross National Happiness. In Karma, U. \& Karma, G., eds., Gross national happiness and development, Proceedings of the First International Seminar on 'Operationalization of Gross National Happiness' (pp. 287-318). Thimphu: Centre for Bhutan Studies.

[79] Voigt, C., Howat, G. \& Brown, G. (2010). Hedonic and eudaimonic experiences among wellness tourists: An exploratory enquiry. Annals of Leisure Research, 13(3), 541-562. DOI: $10.1080 / 11745398.2010 .9686862$.

[80] Williams, P. (2001). Positioning wine tourism destinations: an image analysis. International Journal of Wine Marketing, 13(3), 42-58. DOI: 10.1108/eb008726.

[81] Wu, J. (2010). Pleasure and meaning: The two foundations of happiness. Applied Research in Quality of Life, 5, 79-80. DOI: 10.1007/s11482-010-9093-7.

[82] Yang, J., Gu, Y. \& Cen, J. (2011). Festival tourists' emotion, perceived value, and behavioral intentions: A test of the moderating effect of festivalscape. Journal of Convention \& Event Tourism, 12, 25-44. DOI: 10.1080/15470148.2010.551292. 
[83] Yoon, Y. \& Uysal, M. (2005). An examination of the effects of motivation and satisfaction on destination loyalty: a structural model. Tourism Management, 26(1), 45-56. DOI: 10.1016/j.tourman.2003.08.016.

[84] Yuan, J., Morrison, A. M., Cai, L. A. \& Linton, S. (2008). A model of wine tourist behaviour: a festival approach. International Journal on Tourism Research, 10, 207-219. DOI: $10.1002 /$ jtr.651.

[85] Zhang, H., Wu, Y. \& Buhalis, D. (2018). A model of perceived image, memorable tourism experiences and revisit intention. Journal of Destination Marketing \& Management, 8, 326336. DOI: 10.1016/j.jdmm.2017.06.004.

\section{Other sources}

[86] Bruwer, J., Lesschaeve, I., Gray, D. \& Sottini, V. A. (2013b). Regional brand perception by wine tourists within a winescape framework. Paper presented in the 7th AWBR International Conference, St. Catherines.

[87] Canva.com (2021). Available at: https://www.canva.com.

[88] Čsú (2021). Vinice (strukturální šetření) - 2020 (Vineyards (structural investigation) - 2020). Available at: https://www.czso.cz/csu/czso/vinice-strukturalni-setreni-2020\#.

[89] CzechTourism (2020). Návštěvnost turistických cílů 2019: Jihomoravský kraj (Visits of tourist destinations 2019: South Moravia Region). Available at: https://tourdata.cz/data/navstevnost-turistickych-cilu-jihomoravsky-kraj/.

[90] Czech Statistical Office (2021). Příjezdový a domácí cestovní ruch 2020 (Inbound and domestic tourism 2020). Available at: https://tourdata.cz/data/prijezdovy-a-domaci-cestovniruch-2020/.

[91] Flamik, J. (2020). Když se nechodí pro víno, ale za vínem aneb Stav a perspektivy vinařské turistiky $v$ ČR (When not going for wine, but to wine or the state and perspectives of wine tourism in the Czech Republic). Available at: https://celyoturismu.cz/kdyz-se-nechodi-provino-ale-za-vinem-aneb-stav-a-perspektivy-vinarske-turistiky-v-cr/.

[92] Flamik, J. (2014). Moderní formy vinařské turistiky (Modern forms of wine tourism). Partnerství, o.p.s., v rámci projektu Moderní formy vinařské turistiky.

[93] HledamVino.cz (2018). Vinařské regiony - Česká republika (Wine regions - Czech Republic). Available at: https://www.hledamvino.cz/vinarske-regiony-ceska-republika/.

[94] Laerd Statistics (2018). Kruskal-Wallis H Test using SPSS Statistics. Statistics Laerd. Available at: https://statistics.laerd.com/spss-tutorials/kruskal-wallis-h-test-using-spssstatistics.php.

[95] Nadace Partnerství (2021a). Available at: https://www.nadacepartnerstvi.cz.

[96] Nadace Partnerství (2021b). Moravian wine trails. Moravské Vinarské Stezky. Available at: https://www.vinarske.stezky.cz/uvod?lang=en-US.

[97] Wordart.com (2021). Available at: https://wordart.com/. 